\title{
PERBEDAAN PENERAPAN MANAJEMEN STRES PADA LANSIA YANG TINGGAL DI PANTI DAN LANSIA YANG TINGGAL DENGAN KELUARGA
}

\author{
Neneng Tri Afriani ${ }^{\mathrm{a}}$, Hendro J. Bidjuni ${ }^{\mathrm{b}}$, Dina Mariana Larira ${ }^{\mathrm{c} *}$ \\ a-cProgram Studi Ilmu Keperawatan Fakultas Kedokteran Universitas Sam Ratulangi \\ Corresponding author: dinamariana@unsrat.ac.id
}

\begin{abstract}
Background: Over a period of almost 5 decades, the percentage of Indonesia's elderly population has doubled where the increase in the elderly population has become a global phenomenon. Most of the elderly who live in nursing homes experience stress, while the elderly who live with their families do not experience stress, so stress management for each elderly is generally different. Aim: To find out the difference in the application of stress management for the elderly in nursing homes and those who live with their families. Method: The research method is descriptive analytic with a cross sectional approach where the researcher measures the difference between stress management for the elderly in nursing homes and the elderly with their families. Result: Stress management for the elderly at BPLU Senja Bright Paniki that of 45 respondents found 31 elderly doing good stress management while 14 elderly doing enough stress management, stress management for the elderly at the peaceful orphanage Ranomuut of 13 respondents found 5 elderly doing good stress management while 8 elderly doing adequate stress management, and stress management for the elderly with their families, it was found that from 50 respondents, 34 elderly people did good stress management while 16 elderly did poor stress management. Conclusion: There are differences in the application of stress management for the elderly who live in orphanages and the elderly who live with their families.
\end{abstract}

Keywords: stress management, elderly, nursing home, family

\begin{abstract}
Abstrak
Latar Belakang: Selama kurun waktu hampir 5 dekade, presentasi penduduk lansia Indonesia meningkat dua kali lipat dimana meningkatnya populasi lansia menjadi fenomena global. Sebagian besar lansia yang tinggal di panti werdha mengalami stress sedangkan lansia yang tinggal dengan keluarga sebagian besar tidak mengalami stress sehingga manajemen stress setiap lansia umumnya berbeda. Tujuan: Untuk mengetahui perbedaan penerapan manajemen stress lansia di panti dan yang tinggal dengan keluarga. Metode: Metode penelitian deskriptif analitik dengan pendekatan cross sectional dimana peneliti mengukur perbedaan di antara manajemen stress lansia di panti dan lansia dengan keluarga. Hasil: Manajemen stres lansia di BPLU Senja cerah paniki bahwa dari45 responden didapati 31 lansia melakukan manajemen stress yang baik sedangkan 14 lansia melakukan manajemen stress yang cukup, manajamen stress lansia di panti damai ranomuut dari 13 responden didapati 5 lansia melakukan manajemen stress yang baik sedangkan 8 lansia melakukan manajemen stress yang cukup, dan manajemen stress lansia dengan keluarga didapati bahwa dari 50 responden didapati 34 lansia melakukan manajemen stress yang baik sedangkan 16 lansia melakukan manajemen stress yang buruk. Kesimpulan: Terdapat perbedaan penerapan manajemen stress lansia yang tinggal di panti dan lansia yang tinggal dengan keluarga.
\end{abstract}

Kata kunci: manajemen stress, lansia, panti werdha, keluarga 


\section{PENDAHULUAN}

Penuaan (aging process) merupakan suatu proses biologis yang tidak dapat dihindari dan sudah mulai berlangsung sejak seseorang mencapai dewasa (Mubarak, 2009). Pada tahun 2019, presentasi lansia mencapai $9,60 \%$ atau sekitar 26,54 juta orang. Kondisi ini menunjukkan bahwa Indonesia sedang bertransisi menuju kea rah penuaan penduduk karena presentasi penduduk berusia 60 tahun mencapai di atas $7 \%$ dari keseluruhan penduduk dan akan menjadi negara dengan struktur penduduk tua jika sudah berada lebih dari 10\% (Badan Pusat Statistik, 2019).

Stres merupakan gejala penyakit masa kini yang erat kaitannya dengan adanya kemajuan pesat dan perubahan yang menuntut adaptasi seseorang terhadap perubahan (Rahman, 2016). Hasil penelitian yang dilakukan oleh Selo, dkk (2017) menyatakan bahwa Sebagian besar $(40,7 \%)$ lansia yang tinggal di panti werdha mengalami stres, sedangkan lansia yang tinggal di luar panti werdha Sebagian bessar $(47,6 \%)$ tidak mengalami stres. Hal ini dikarenakan lansia tidak tinggal dengan keluarga sehingga kemungkinan lansia dalam hidupnya merasa sendiri dan tidak ada yang memberi semangat.

Salah satu hal yang dapat dilakukan untuk membantu mengatasi hal tersebut yaitu dengan melakukan manajemen stres yakni dimana individu melakukan pengontrolan atau pengaturan stres yang bertujuan untuk mengenal penyebab stres dan mengetahui teknik-teknik mengelola stres, sehingga seseorang lebih baik dalam menguasai stres (Segarahayu, 2013).

Berdasarkan penelitian Putu Ayu Sani (2015) manajemen stress pada lansia di rumah yaitu Terapi Reminiscence dapat menurunkan tingkat stress pada lansia karena memiliki fungsi escapist yaitu mengingat keindahan masa lalu untuk melupakan sejenak hal-hal yang tidak menyenangkan dan mengurangi perasaan negatif lansia, sehingga lansia akan terhindar dari stress.

Studi pendahuluan yang diperoleh di Panti Werdha Ranomuut 18 orang lansia, Panti Werdha Senja Cerah 53 lansia dari beberapa lansia tersebut didapati beberapa lansia yang mengalami stress seperti tidak mau bergabung dengan lansia lainnya dan lebih memilih sendiri dan kurang bersosialisasi, dari hasil wawancara dengan lansia ternyata mereka merasa terasingkan dan kesepian akibat keluarganya yang meninggalkan mereka di Panti Werdha sedangkan mereka ingin berkumpul dengan anak dan cucu mereka di rumah dan menikmati masa tua mereka dengan dukungan keluarga yang dicintai. Sedangkan studi pendahuluan yang diperoleh dari lansia yang tinggal di rumah bertempat di lingkungan 1-4 kecamatan bunaken kelurahan Bailing, sebagian lansia mengaku merasa nyaman di rumah bersama anak dan bermain dengan cucunya tetapi ada juga yang mengaku lebih nyaman hidup sendiri karena dengan anak dan cucu dirinya selalu lelah mengerjakan pekerjaan rumah mengurus cucu di rumah, mereka mengatakan keadaan tersebut yang mengakibatkan stress.

Sehingga berdasarkan uraian di atas, peneliti tertarik untuk melakukan penelitian tentang manajemen stres pada lansia di panti werdha dan di rumah. Adapun tujuan dari penelitian ini yaitu untuk mengetahui perbedaan penerapan manajemen stress lansia di panti dan yang tinggal dengan keluarga.

\section{METODE}

Desain penelitian yang digunakan dalam penelitian ini adalah metode penelitian deskriptif analitik dengan pendekatan cross-sectional dimana peneliti mengukur perbedaan antara manajemen stress lansia di panti dan lansia dengan keluarga.

Penelitian ini dilakukan di Panti Werdha yang ada di kota Manado dan Kelurahan Bailang Lingkungan 1-4 yang 
dilakukan pada tanggal 15 Juni - 13 Juli 2020. Populasi pada penelitian ini adalah seluruh lansia yang ada di panti Werdha di kota Manado, dengan total 63 lansia di panti Werdha Damai Ranomuut 13 orang lansia, panti werdha senja cerah 50 lansia dan seluruh lansia yang tinggal di Kelurahan Bailang lingkungan 1-4, yaitu total 52 lansia.

Pengambilan sampel dilakukan dengan menggunakan teknik purposive sampling yaitu teknik penentuan sampel dengan pertimbangan tertentu, karena tidak semua sampel memiliki kriteria sesuai dengan yang telah penulis tentukan (Sugiyono, 2017). Kriteria pemilihan sampel terbagi menjadi kriteria inklusi dan eksklusi. Sampel yang digunakan yaitu lansia yang mengalami stress yang didapati dari kuesioner screening stress. Adapun kriteria inklusi dari penelitian ini yaitu lansia yang pernah atau sedang mengalami stres dan lansia yang bersedia menjadi responden, sedangkan kriteria eksklusi yaitu lansia yang kesulitan berkomunikasi dan lansia yang mengalami demensia. Sampel yang digunakan dalam penelitian ini yaitu BPLU Senja Cerah Paniki sebanyak 45 lansia, Panti Damai Ranomuut 13 lansia, dan di Kelurahan Bailang 50 lansia.

Instrumen penelitian yang digunakan dalam penelitian ini yaitu instrumen penilaian stres dan manajemen stres. Instrumen penilaian stres menggunakan kuesioner Perceived Stress Scale yang digunakan sebagai screening dalam penelitian, terdiri dari 10 item yang berisi tentang perasaan tidak terprediksi (feeling of unprecdictability) pertanyaan nomor 1, perasaan tidak terkontrol (feeling of uncontrollability) pertanyaan nomor 2,6 , 9 dan perasaan tertekan (feeling of overloaded) pertanyaan nomor 3 dan 10 . Variabel berskala numerik yang telah diperoleh dari PSS-10 kemudian diubah menjadi skala ordinal dengan menjadi 3 kelompok yaitu stress ringan (total skor 0-
13), stres sedang (total skor 14-26), dan stres berat (total skor 27-40).

Instrumen penelitian menggunakan lembar checklist adalah daftar pengecek, berisi nama subjek dan beberapa gejala/identitas lainnya dari sasaran pengamatan. Pada penelitian ini peneliti hanya tinggal menilai dan memberikan tanda atau checklist di setiap permunculan gejala lengkap atau tidak lengkapnya sasaran pengamatan. Lembar checklist terdiri dari aspek manajemen stress yang didapat dari "stress management for seniors checklist”.

Uji statistik yang digunakan dalam penelitian ini adalah uji independent t test. Uji independent t test adalah uji beda untuk mengetahui adakah perbedaan antara 2 kelompok yang tidak berpasangan. Syarat uji ini adalah data berdistribusi normal dan varians kelompok sama atau homogen.

\section{HASIL}

\section{Screening Tingkat Stres pada Lansia}

Sebelum dilakukan penelitian, peneliti melakukan screening menggunakan koesioner perceived stress scale melalui google form pada lansia yang berada di BPLU Senja Cerah Paniki, Panti Wredha Damai Ranomuut dan Kelurahan Bailang Lingkungan 1-4. 
Jurnal Keperawatan, Volume 9, No. 1, Februari 2021, (Hal. 78-86)

Tabel 1. Screening Tingkat Stres Lansia

\begin{tabular}{clcc}
\hline No & \multicolumn{1}{c}{ Tingkat Stres } & $\mathrm{f}$ & $\%$ \\
\hline 1. & BPLU Senja Cerah Paniki & & \\
& $-\quad$ Stres ringan & 17 & 34 \\
& $-\quad$ Stres sedang & 13 & 26 \\
& - Stres berat & 20 & 40 \\
$\quad$ Total & 50 & 100 \\
\hline 2. & Panti Werdha Ranomuut & & \\
& - Stres ringan & 4 & 30,8 \\
& - Stres sedang & 4 & 30,8 \\
& - Stres berat & 5 & 38,5 \\
Total & 13 & 100 \\
\hline Kelurahan Bailang & & \\
& $-\quad$ Stres ringan & 18 & 34,6 \\
& - Stres sedang & 23 & 44,2 \\
& Ttres berat & 11 & 21,2 \\
& Total & 52 & 100 \\
\hline
\end{tabular}

Sumber data, 2020

Tabel 1 di atas menunjukkan bahwa terdapat 50 lansia di BPLU Senja Cerah Paniki yang melakukan screening dengan cara mengisi kuesioner perceived stress scale melalui google form dimana hasil yang didapati lansia yang mengalami stress ringan 17 orang, stress sedang 13 orang dan 20 orang stress berat. Sedangkan, di Panti Werdha Ranomuut terdapat 13 lansia yang melakukan screening dengan hasil yang didapati yaitu yang mengalami stress ringan 4 orang, stress sedang 4 orang dan 5 orang stress berat. Sementara itu, terdapat 52 lansia yang melakukan screening dengan hasil yang didapati lansia yang mengalami stress ringan 18 orang, stress sedang 23 orang dan 11 orang stress berat. 
Jurnal Keperawatan, Volume 9, No. 1, Februari 2021, (Hal. 78-86)

\section{Analisis Univariat}

Tabel 2. Distribusi Karakteristik Responden pada Lansia

\begin{tabular}{|c|c|c|c|c|c|}
\hline \multirow[t]{2}{*}{ No } & \multirow{2}{*}{ Variabel } & \multicolumn{2}{|c|}{ Panti } & \multicolumn{2}{|c|}{ Rumah } \\
\hline & & $\mathbf{f}$ & $\%$ & $\mathbf{f}$ & $\%$ \\
\hline \multicolumn{6}{|c|}{ 1. Usia } \\
\hline & $-\quad 45-59$ & 12 & 20,6 & 9 & 18 \\
\hline & $-\quad 60-74$ & 26 & 44,8 & 26 & 52 \\
\hline & $-75-90$ & 20 & 34,4 & 15 & 30 \\
\hline \multicolumn{6}{|c|}{ 2. Jenis Kelamin } \\
\hline & - Laki-laki & 7 & 12,0 & 11 & 20,4 \\
\hline & - Perempuan & 51 & 87,9 & 39 & 79,6 \\
\hline \multicolumn{6}{|c|}{ Manajemen Stres } \\
\hline & - Baik & 19 & 32,7 & 34 & 68,0 \\
\hline & - Cukup & 39 & 67,2 & 16 & 32,0 \\
\hline & Total & 58 & 100 & 50 & 100 \\
\hline
\end{tabular}

Sumber data, 2020

Tabel 2 di atas menunjukan bahwa dari total lansia di panti 58 responden, usia (60-74) merupakan kelompok usia terbanyak dengan jumlah 26 orang $(44.8 \%)$, kelompok usia (75-90) berada pada urutan kedua dengan jumlah 20 orang (34.4\%), sedangkan kelompok usia (45-59) berada pada urutan terbawah dengan jumlah 12 orang $(20.6 \%)$. Sedangkan di rumah dari total lansia 50 responden, usia (60-74) merupakan kelompok usia terbanyak dengan jumlah 26 orang (52\%), kelompok usia (7590) berada pada urutan kedua dengan jumlah 15 orang (30\%), sedangkan kelompok usia (45-59) berada pada urutan terbawah dengan jumlah 9 orang (18\%). Sedangkan dari total lansia di panti, responden berjenis kelamin perempuan merupakan kelompok terbanyak dengan jumlah 51 orang $(87.9 \%)$, dan responden berjenis kelamin laki-laki hanya berjumlah 7 orang $(12,0 \%)$. Sementara itu lansia yang berada di rumah, berjenis kelamin perempuan merupakan kelompok terbanyak dengan jumlah 39 orang $(79,6 \%)$, dan berjenis kelamin laki-laki hanya berjumlah 11 orang $(20,4 \%)$. Dari segi manajemen stres di panti ditemukan sebanyak 19 lansia $(32,7 \%)$ melakukan manajemen stres yang baik sedangkan 39 lansia $(67,2 \%)$ melakukan manajemen stres yang cukup. Sedangkan, dari total lansia di rumah didapati 34 lansia $(68,0 \%)$ melakukan manajemen stres baik dan 16 lansia $(32,0 \%)$ melakukan manajemen stres yang cukup.

\section{Analisis Bivariat}

\section{a. Uji Normalitas}

Langkah utama yang dilakukan peneliti dalam melakkan uji hipotesis adalah uji normalitas. Uji normalitas menggunakan kolmorgov smirnov, dikarenakan sampel yang digunakan lebih dari 50 sampel dimana dengan teknik ini suatu data dapat dikatakan normal apabila memiliki nilai signifikansi atau nilai alpha sebesar 0,05 (p > 0,05). Diketahui bahwa data berdistribusi normal, hal itu dikarenakan nilai signifikansi $\mathrm{p}=0,056$, dan nilai tersebut lebih besar dari 0,05 ( $\mathrm{p}>$ $0,05)$.

\section{b. Uji Homogenitas}

Uji homogenitas digunakan untuk memperlihatkan bahwa dua atau lebih kelompok data sampel berasal dari populasi yang memiliki variasi yang sama. Data homogenitas apabila nilai signifikan lebih besar 0,05 pada $(\mathrm{p}>0,05)$. Dari data yang didapat diketahui bahwa data homogenitas, dikarenakan nilai 
signifikansi $p=0,747$ dan nilai tersebut lebih besar dari 0,05 ( $\mathrm{p}>$ $0,05)$.

\section{c. Uji Bivariat}

Tabel 3. Hasil Uji Analisis Bivariat

\begin{tabular}{ccc}
\hline Manajemen Stres & Rerata & Nilai p \\
\hline Lansia di panti & 3,71 & 0,004 \\
Lansia di rumah & 4,14 & \\
\hline
\end{tabular}

Uji t tidak berpasangan

Dari hasil analisis data secara uji $\mathrm{T}$ tidak berpasangan (Uji Beda) diperoleh bahwa terdapat perbedaan yang signifikan antara manajemen stress lansia di panti dan manajemen stress lansia dengan keluarga. Pengujian hipotesis ditemukan bahwa nilai probabilitas sig 0,004 yang berarti sig $<0,05$ maka H1 diterima berarti variabel manajemen stress mempunyai varian yang tidak sama (tidak identik). Sehingga dapat disimpulkan bahwa manajemen stress lansia di panti berbeda dengan manajemen stress lansia dengan keluarga.

\section{PEMBAHASAN}

\section{Karakteristik Responden Berdasarkan Usia}

Berdasarkan hasil temuan peneliti di BPLU Senja cerah paniki yang dilakukan dengan cara mengisi google form yang di bantu oleh perawat yang ada di panti, menunjukan bahwa dari total 45 responden, usia (60-74) merupakan kelompok usia terbanyak dengan jumlah 22 orang $(48,9 \%)$, kelompok usia (75-90) berada pada urutan kedua dengan jumlah 14 orang $(31,1 \%)$, sedangkan kelompok usia (45-59) berada pada urutan terbawah dengan jumlah 9 orang (18\%). Sedangkan di panti damai ranomuut peneliti melakukan penelitian secara lansung dengan memberikan cara wawancara dan memberikan kuesioner kepada lansia di panti dan menunjukan bahwa dari total 13 responden, usia (75-90) merupakan kelompok usia terbanyak dengan jumlah 6 orang (46,2\%), kelompok usia (6074) berada pada urutan kedua dengan jumlah 4 orang $(30,8 \%)$, sedangkan kelompok usia (45-59) berada pada urutan terbawah dengan jumlah 3 orang $(23,1 \%)$. Hal ini dikarenakan lansia yang berumur lanjut usia tua sering berfikiran negatif dan memiliki harapan hidup yang kecil sehingga memicu stres yang berkepanjangan. Berdasarkan hasil yang didapati di rumah bertempat di Kelurahan Bailang, peneliti melakukan survey langsung dengan cara wawancara dan memberikan kuesioner kepada lansia dimana dari hasil wawancara menunjukkan bahwa dari total 50 responden, usia (60-74) merupakan kelompok usia terbanyak dengan jumlah 26 orang (52\%), kelompok usia (75-90) berada pada urutan kedua dengan jumlah 15 orang (30\%), sedangkan kelompok usia (45-59) berada pada urutan terbawah dengan jumlah 9 orang (18\%). Pernyataan di atas didukung oleh penelitian yang dilakukan oleh Nora Maulina dengan judul "Gambaran Tingkat Stres pada Lansia di Panti Jompo Kota Lhokseumawe Tahun 2017" yang menyatakan bahwa stres menjadi kronis biasanya muncul untuk pertama kalinya pada umur 60 tahun ke atas, walaupun demikian stres juga dapat terjadi pada orang dewasa dan pada umumnya lanjut usia dan lanjut usia tua sering memikirkan hal-hal negatif mengenai diri sendiri dan masa depan sehingga memicu stres berkepanjangan. 


\section{Karakteristik Responden Berdasarkan Jenis Kelamin}

Berdasarkan hasil temuan peneliti menunjukkan bahwa di BPLU Senja cerah paniki dari total 45 responden, responden berjenis kelamin perempuan merupakan kelompok terbanyak dengan jumlah 38 orang $(84,6 \%)$, sedangkan responden berjenis kelamin laki-laki hanya berjumlah 7 orang $(15,6 \%)$. Hal ini menunjukan bahwa dari total 13 responden, usia (75-90) merupakan kelompok usia terbanyak dengan jumlah 6 orang $(46,2 \%)$, kelompok usia (6074) berada pada urutan kedua dengan jumlah 4 orang $(30,8 \%)$, sedangkan kelompok usia (45-59) berada pada urutan terbawah dengan jumlah 3 orang $(23,1 \%)$. Dan lansia di rumah bertempat di Kelurahan Bailang menunjukan bahwa dari total 50 responden, responden berjenis kelamin perempuan merupakan kelompok terbanyak dengan jumlah 39 orang $(79,6 \%)$, sedangkan responden berjenis kelamin laki-laki hanya berjumlah 11 orang $(20,4 \%)$. Perrnyataan di atas didukung oleh penelitian yang dilakukan oleh Nora Maulina dengan judul "Gambaran Tingkat Stres pada Lansia di Panti Jompo Kota Lhokseumawe Tahun 2017" yang menyatakan bahwa ada perbedaan respon antara laki-laki dan perempuan saat menghadapi konflik dan stres, pada perempuan konflik memicu hormon negatif sehingga memunculkan stres, gelisah, rasa takut. Sedangkan lakilaki umumnya menikmati adanya konflik dan persaingan, bahkan menganggap bahwa konflik dapat memberikan dorongan yang positif. Dengan demikian, perempuan ketika mengalami tekanan pada umumnya akan lebih mudah mengalami stres.

\section{Karakteristik Responden Berdasarkan Manajemen Stres}

Berdasarkan temuan yang didapati peneliti di BPLU Senja cerah paniki bahwa dari 45 responden didapati 31 lansia melakukan manajemen stres yang baik, sedangkan 14 lansia melakukan manajemen stres yang cukup. Di lain sisi, panti Damai
Ranomuut dari 13 responden didapati 5 lansia melakukan manajemen stres yang baik sedangkan 8 lansia melakukan manajemen stres yang cukup. Hal ini dikarenakan lansia yang berada di panti umumnya kurang melakukan aktivitas sehingga memicu manajemen stres yang cukup dikarenakan lansia lebih banyak beristirahat di kamar masing-masing. Berbeda dengan lansia di rumah bertempat di Kelurahan Bailang didapati bahwa dari 50 responden didapati 34 lansia melakukan manajemen stres yang baik, sedangkan 16 lansia melakukan manajemen stres yang cukup. Hal ini diakibatkan karena lansia yang berada di rumah lebih banyak melakukan aktifitas seperti melakukan pekerjaan rumah. Pernyataan di atas didukung oleh penelitian Febriyanti Mendoko tahun 2017 dengan judul “ Perbedaan Status Psikososial Lanjut Usia yang Tinggal di Panti Werdha Damai Ranomuut Manado dengan yang tinggal bersama keluarga di Desa Sarongsong II Kecamatan Airmadidi Kabupaten Minahasa Utara" yang menyatakan bahwa mekanisme koping pada lansia yang berada di rumah yaitu dengan cara mereka menceritakan masalah dengan pasangan, anak dan teman mereka sehingga mereka mendapatkan solusi yang terbaik dari permasalahan yang dihadapi lansia, sedangkan mekanisme koping pada lansia yang berada di panti mereka hanya dapat bercerita dengan teman tanpa bisa bercerita dengan anak atau cucu mereka. Faktor lain yang mempengaruhi lansia yang tinggal di rumah bersama keluarga secara fisik, psikologis, dan kepuasannya terhadap lingkungan lebih tinggi daripada lansia yang tinggal di panti werdha. Keadaan ini dikarenakan lansia memiliki keterikatan dengan rumahnya, sehingga lansia merasa memiliki kontrol, rasa aman, dan perasaan yang positif sehingga manajemen stres lansia di rumah lebih baik dibandingkan lansia yang tinggal di panti. 


\section{Perbedaan Penerapan Manajemen Stress Lansia di Panti dan yang Tinggal dengan Keluarga}

Dari hasil analisis data secara uji independent T-test (Uji Beda) diperoleh bahwa terdapat perbedaan yang signifikan antara manajemen stress lansia di panti dan manajemen stress lansia dengan keluarga, Pengujian hipotesis ditemukan bahwa nilai probabilitas sig 0,004 yang berarti sig $<0,05$ maka H1 diterima berarti variabel manajemen stress mempunyai varian yang tidak sama (tidak identik). Dengan demikian manajemen stress lansia di panti berbeda dengan manajemen stress lansia dengan keluarga. Hal ini di lihat dari hasil lembar checklist manajemen yang diberikan kepada lansia dan didapati lansia yang tinggal di panti dominan melakukan manajemen stres teman dan istirahat, sedangkan lansia yang tinggal di rumah lebih dominan melakukan manajemen stres keluarga dan bekerja.

Penelitian ini diharapkan sebagai tambahan ilmu bagi keperawatan jiwa, dalam melakukan manajemen stres pada lansia di panti dan lansia yang tinggal dengan keluarga. Dilihat dari hasil dan pembahasan peneliti ada beberapa manajemen stres lansia yag dapat di lakukan di panti dan di rumah sehingga dapat membantu lansia untuk mengurangi stres yang dialami lansia.

\section{SIMPULAN}

1. Manajemen Stres lansia di BPLU Senja cerah paniki dan di Panti Damai Ranomuut yaitu teman dan istirahat/tidur, dimana lansia di panti memiliki manajemen stres yang Cukup.

2. Manajemen Stres lansia dengan keluarga yang bertempat di Kelurahan Bailang Kecamatan Bunaken yaitu keluarga dan bekerja, dimana lansia dengan keluarga memiliki manajemen stres yang baik.

3. Terdapat perbedaan penerapan manajemen Stres lansia yang tinggal di panti dan lansia yang tinggal dengan keluarga.

\section{DAFTAR PUSTAKA}

Azizah, R dan R. D. Hartatnti. 2016. Hubungan antara Tingkat Stres dengan Kualitas Hidup Lansia Hipertensi di Wilayah Kerja Puskesmas Wonopringgo Pekalongan. The 4 th University Research Coloqium. 261278.

Badan Pusat Statistika (BPS), Bappenas, UNFPA, 2019.

Hubungan tingkat stress dengan gangguan tidur pada mahasiswa skripsi di salah satu fakultas rumpun sciencetechnology UI oleh Resti Putri Wulandari,2012

Hawari, (2011). Manajemen stress cemas dan depresi. FKUI: Jakarta

Iyus Yosep. 2013. Keperawatan Jiwa. Bandung. PT. Refika Aditama.

Kusumowardani, A dan Puspitosari, A. 2014. Hubungan Antara Tingkat Depresi Lansia dengan Interaksi Sosial Lansia di Desa sobokerto Kecamatan Ngemplak Boyolali. Jurnal Terpadu Ilmu Kesehatan, 3(2): 106-214

Mayasari, L. 2012. "Mana Lebih Baik, Hidup di Panti Jompo atau Tinggal dengan Anak Saat Tua". detikHealth, 10 September 2012.

Nugroho. (2012). Keperawatan gerontik \& geriatrik, edisi 3. Jakarta: EGC

Notoatmodjo S. Promosi Kesehatan dan Ilmu Perilaku. Jakarta: PT Rineka Cipta; 2011.

Padila. (2013). Buku Ajar Keperawatan Gerontik. Yogyakarta: NuMed

Putri, R. D. 2012. Perbedaan Tingkat Stres Pada Lansia Yang Bertempat Tinggal di Rumah Dan Di UPT Pelayanan Sosial Lanjut Usia Bondowoso. Skripsi. Program Studi Ilmu Keperawatan Universitas Jember. Jember.

Sarafino, E P., \& Smith, T. W. (2011). Health Psychology: biopsychosocial interactions ( $7^{\text {th }}$ edition).USA: John wiley \& sons, incHawari

Rahman, S. 2016. Faktor-faktor yang Mendasari Stres pada Lansia. Jurnal 
Jurnal Keperawatan, Volume 9, No. 1, Februari 2021, (Hal. 78-86)

Pendiidkan Indonesia 16 (1): 1-7.

Sarafino, E P., \& Smith, T. W. (2011).

Health Psychology: biopsychosocial

interactions ( $7^{\text {th }}$ edition).USA: John

wiley \& sons, incHawari

Segarahayu, R. D. (2013). Pengaruh manajemen stres terhadap penurunan tingkat stres pada narapidana di LPW Malang. UM the Learning University, $1(1)$.

Selo, J., E. Candrawati dan R. M. Putri. 2017. Perbedaan Tingkat Stres pada Lansia di Dalam dan di Luar Panti Werdha Pangesti Lawang. Nursing News 2 (3): 522-533

Sari, Y.N.E., 2015. Buku Ajar Psikologi Pendidikan. Yogyakarta: Parama Publishing.

Setyawan, A. B., 2017. Hubungan Antara Tingkat Stres dan Kecemasan dengan Kejadian Hipertensi pada Lansia di Klinik Islamic Center Samarinda. Jurnal Ilmu Kesehatan, Volume 5, p. 68. 